\title{
Development of a Standard Moodle Course to Optimize the Teacher's Work in Distance Education
}

\author{
Iryna S. Mintii ${ }^{1}$, Svitlana V. Shokaliuk ${ }^{1}$, Tetiana A. Vakaliuk ${ }^{2, *}$, Olexandr V. Merzlykin ${ }^{3}$, \\ Mykhailo M. Mintii ${ }^{1}$

\begin{abstract}
${ }^{1}$ Department of Computer Science and Applied Mathematics, Faculty of Physics and Mathematics, Kryvyi Rih State Pedagogical University, Ukraine Ukraine

${ }^{3}$ Kryvyi Rih Educational Complex No 129 "Gymnasium-Lyceum of Academic Approach", Ukraine
\end{abstract} \\ ${ }^{2}$ Department of Software Engineering, Faculty of Information and Computer Technologies, Zhytomyr Polytechnic State University,
}

Received July 15, 2020; Revised August 13, 2020; Accepted November 19, 2020

\section{Cite This Paper in the following Citation Styles}

(a): [1] Iryna S. Mintii, Svitlana V. Shokaliuk, Tetiana A. Vakaliuk, Olexandr V. Merzlykin, Mykhailo M. Mintii, "Development of a Standard Moodle Course to Optimize the Teacher's Work in Distance Education," Universal Journal of Educational Research, Vol. 8, No. 12, pp. 6659-6666, 2020. DOI: 10.13189/ujer.2020.081230.

(b): Iryna S. Mintii, Svitlana V. Shokaliuk, Tetiana A. Vakaliuk, Olexandr V. Merzlykin, Mykhailo M. Mintii (2020). Development of a Standard Moodle Course to Optimize the Teacher's Work in Distance Education. Universal Journal of Educational Research, 8(12), 6659-6666. DOI: 10.13189/ujer.2020.081230.

Copyright $\subseteq 2020$ by authors, all rights reserved. Authors agree that this article remains permanently open access under the terms of the Creative Commons Attribution License 4.0 International License

\begin{abstract}
To minimize the time required for designing a Moodle course and to reduce the required level of ICT competence for learning content management system (LCMS) Moodle, we designed standard Moodle course university and created video tutorials about how to design a new Moodle course based on it. The purpose of this paper is to consider the structural and content features of the standard Moodle course university and to review the methodical instructions for designing a new Moodle course based on it. The reasonableness of the creation of a new Moodle course from a backup copy of the standard course university is substantiated in the work. This approach to new courses designing eliminates two main factors that impede using of Moodle in the educational process. When a teacher has electronic training and methodological complex, this approach helps to minimize the time for course designing. Using of such elements as "URL", "Assignment" and "Quiz" reduces the minimal level of teachers' information and communication technologies competence for work in Moodle. The basic principle of building a standard course is the designing course as the online portal. When course is built in this way, it helps not to overload the Moodle server. Placing of electronic learning and methodological complex components on Google Drive creates the first backup of the course. The following methods were used in the research: analysis of
\end{abstract}

Internet resources (finding out which Ukrainian pedagogical universities use LCMS Moodle), analysis of a pedagogical experience of using LCMS Moodle, modeling (developing a model of standard Moodle course and its use in the educational process), questionnaires (finding out whether the model meets the requirements of the educational process and the direction of further research).

Keywords Learning Content Management System Moodle, Standard Course, Backup of the Course, Distance Education

\section{Introduction}

Today it is very important to train teachers for using of distance technologies in the educational process. Today there are such Ukrainian-language online educational platforms: "Action. Digital education" [11] - educational series "Digital skills for teachers" and "Quarantine: online services for teachers"; "For The Lesson" [12] - courses "Teaching informatics through distance learning", "Class Dojo and other feed-back tools", "Using Zoom service for distance lessons", etc. Also there are courses at higher education institutions sites: National Technical University 
"Kharkiv Polytechnic Institute" [10] - courses "Technology of Distance Course Design 2020" and "Basics of Distance Learning 2020"; Zhytomyr Polytechnic State University [23] - Course "Cloud Technologies in Distance Learning During Quarantine" and others.

However, analysis of the such scientists as Yu.V. Tryus[21; 20], V.M. Kukharenko [7], S.O. Semerikov[14; $15 ; 19]$, Ye.M. Smyrnova-Trybulska[16], etc. makes us to conclude that for higher education blended learning is more appropriate than distance learning: "blended learning is one of the most promising innovation trends in higher education" [21, p. 299].

In 2016, Gartner analysts determined that blended learning reached the plateau of productivity, and therefore matured, and its' benefits are undoubted [1] (Fig. 1).

A.M. Striuk defines blended learning as "the way of realizing the content of learning that integrates classroom and online learning activities with pedagogically balanced combination of traditional, electronic, distance and mobile learning technologies with the aim to achieve learning goals most efficiently" [18, p. 19].

Depending on the technical capabilities of Universities and the level of its' teaching staff, it is possible to combine the following types of student learning activities under the guidance of the teacher in blended learning [21, p. 304]:

- traditional workshops or seminars with video conferences and webinars;

- traditional lessons with their discussion at forums, chats or using e-mail;

- group work on individual tasks with their discussion at the class;

- Internet lectures with workshops and labs at the class;

- lectures at the class and teachers' Internet consulting;

- individual tasks with sending results to the teacher via Internet services;

- implementation of role-playing games and research projects in the virtual environment at home or at class; - other combinations of using the distance, electronic, mobile learning and traditional learning forms, methods and tools.

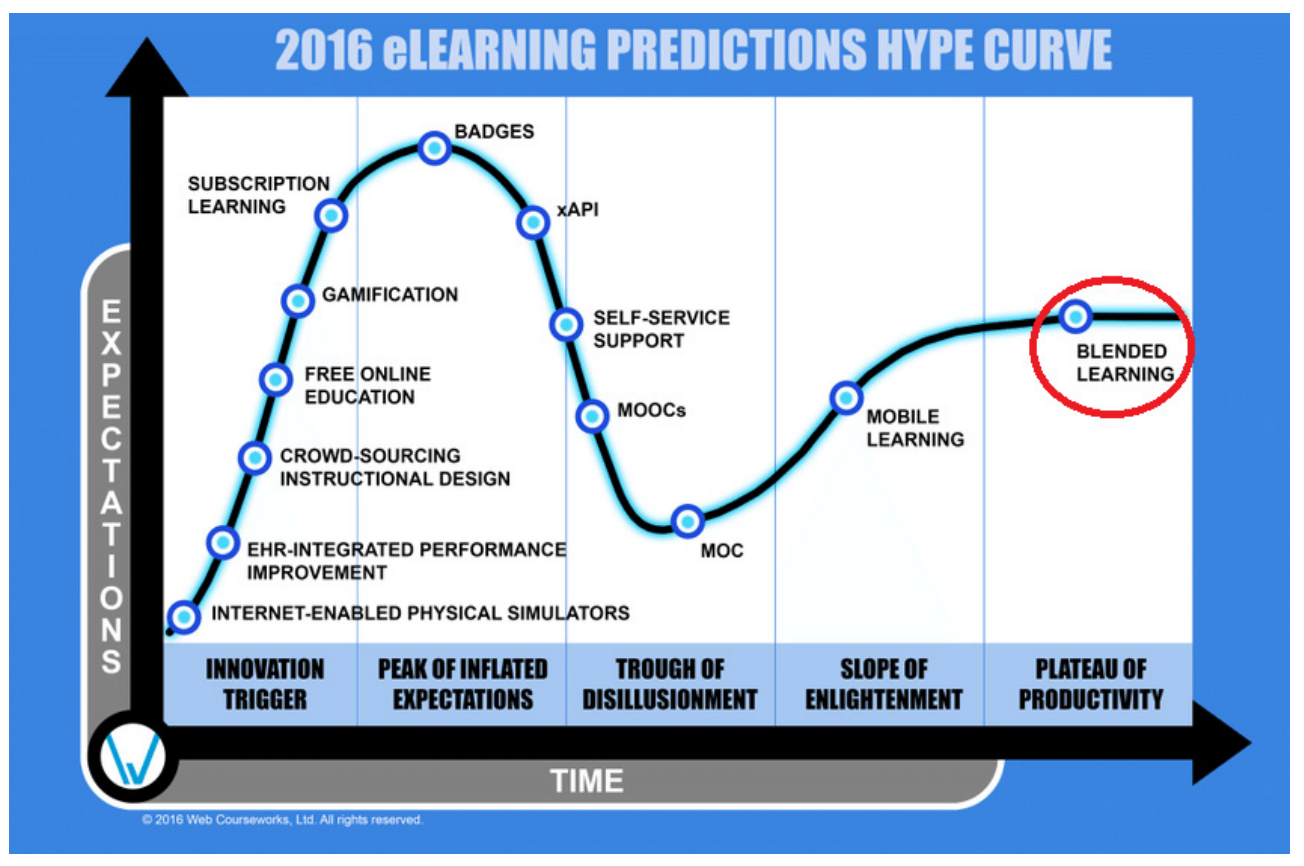

Figure 1. 2016 eLearning Predictions Hype Curve 


\section{Materials and Methods}

According to the European University Association report, $91 \%$ of universities use blended learning, $82 \%$ of universities offer online courses, over $80 \%$ of universities have repositories for storing e-courses and digital content, and various systems for creating and managing educational resources for students [3].

Because of its' wide range of capabilities and simple interface, LCMS Moodle is one of the most popular platforms for blended learning. The LCMS Moodle module structure makes it easy to modify the design. Another Moodle advantage is the availability of more than 40 language packages.

As a result of the analysis of Internet resources, it is determined that the vast majority $(86 \%)$ of Ukrainian Universities, which provide training in pedagogical specialties, use LCMS Moodle. Among them are Berdyansk State Pedagogical University [24], Bogdan Khmelnytsky Cherkasy National University [25], Borys Grinchenko Kyiv University [26], Donbass State Pedagogical University [27], H.S. Skovoroda Kharkiv National Pedagogical University [28], Ivan Franko Lviv National University [29], Kamianets-Podilskyi National Ivan Ohiienko University [30], Khmelnytskyi National University [31], Kryvyi Rih State Pedagogical University [32], Kherson State University [33], Lesya Ukrainka Eastern European National University [34], Luhansk Taras Shevchenko National University [35], Makarenko Sumy State Pedagogical University [36], Mykolaiv V. O. Sukhomlynskyi National University [37], National Pedagogical Dragomanov University [38], Pavlo Tychyna Uman State Pedagogical University [39], Rivne State University of Humanities [40], Taras Shevchenko National University "Chernihiv College" [41], Ternopil Volodymyr
Hnatiuk National Pedagogical University [42], Uzhhorod National University [43], Vinnytsia Mykhailo Kotsiubynskyi State Pedagogical University [44], Volodymyr Vynnychenko Central Ukrainian State Pedagogical University [45], Yuriy Fedkovych Chernivtsi National University [46], Zhytomyr Ivan Franko State University [47].

Teaching staff training to design Moodle courses in Universities is carried out according to their own educational trajectories: self-education using instructions in different formats (text, video) $[4 ; 5 ; 8 ; 13 ; 20 ; 22]$, intensive trainings [40;42], long-term courses on enhancing their ICT competence [9] and others.

We designed survey "Using LCMS Moodle in the University Educational Process" and did this research in 2019-2020. Its' results are:

- factors that hinder the use of LCMS Moodle in the educational process are the lack of time $(48 \%$ of surveyed teachers) and low level of IT competence ( $29 \%$ of surveyed teachers);

- ways to increase the IT competence by using LCMS Moodle are self-education, communication with colleagues, IT courses, webinars, workshops, seminars. The distribution of the respondents is shown at the Fig. 2;

- ways to increase the use of LCMS Moodle in the educational process are periodic seminars, consultations on basic LCMS Moodle capabilities (as an option, group or personal electronic appointment with a qualified specialist); site stability; blended ICT courses; development of methodological guidelines of using some elements in the educational process; creation of transparent, predictable and attractive for authors license and course sample.

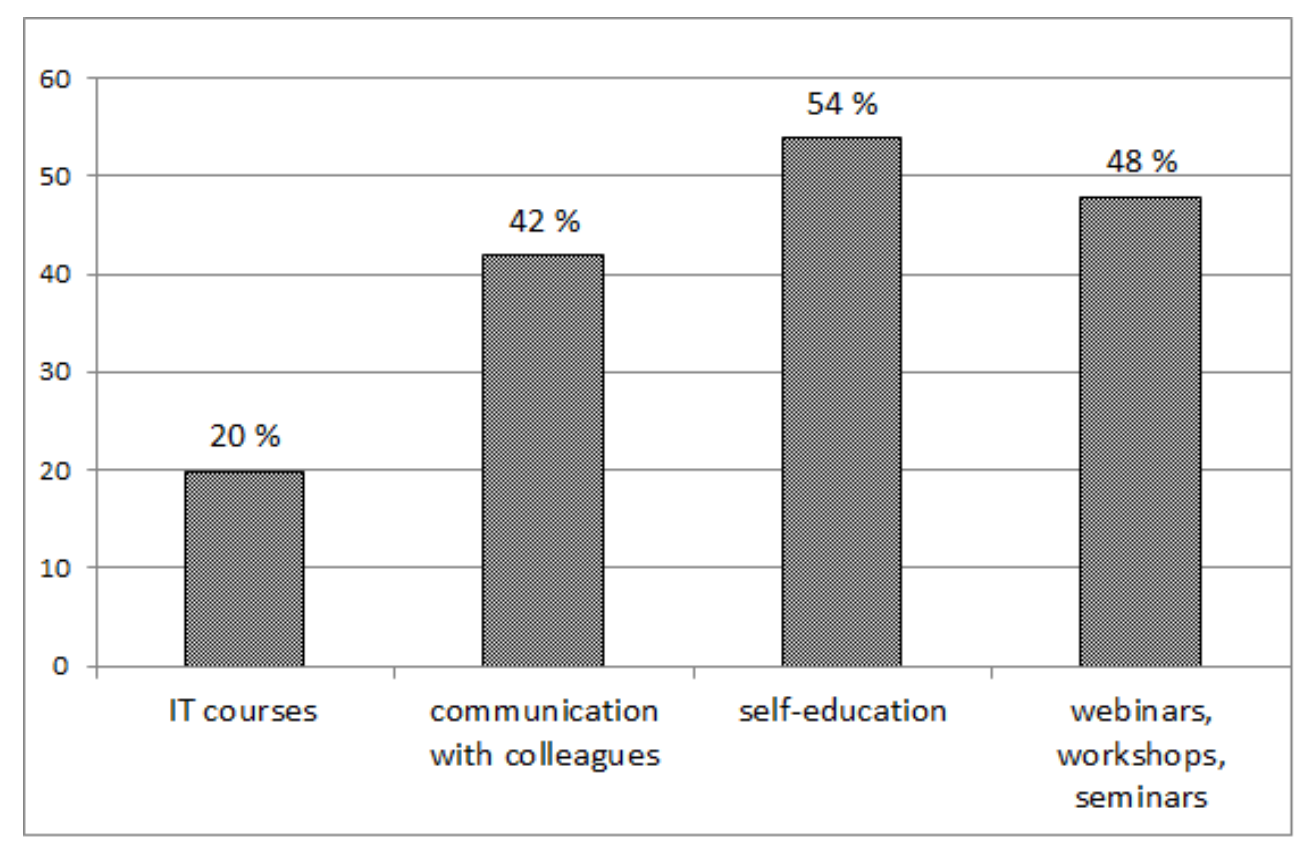

Figure 2. Ways to improve Moodle competencies 
To minimize the time required for designing a Moodle course and to reduce the required level of ICT competence for LCMS Moodle, we designed standard Moodle course university and created video tutorials about how to design a new Moodle course based on it [6]. The principle of course design will improve the site stability.

The purpose of this paper is to consider the structural and content features of the standard Moodle course university and to review the methodical instructions for designing a new Moodle course based on it.

The following methods were used in the research: analysis of Internet resources (finding out which Ukrainian pedagogical universities use LCMS Moodle), analysis of a pedagogical experience of using LCMS Moodle, modeling (developing a model of standard Moodle course and its use in the educational process), questionnaires (finding out whether the model meets the requirements of the educational process and the direction of further research).

\section{Results}

\subsection{The Basic Principle of Designing}

The basic principle of designing the course is to consider course as an information portal. It means that this course contains educational materials from different sources. Electronic learning management complex (ELMC) components placed in remote repositories. The main remote repository is personal or departmental corporate (and therefore unlimited) Google Drive [6]. Placing basic information material outside the course site and using web 2.0 services for online meetings and discussions are principles of designing massive open online courses.

\subsection{Structure of the ELMC Placing on Google Drive}

\section{Documentation}

\section{Individual works}

\section{Laboratory works}

\section{Lectures}

\section{a Workshops}

Figure 3. Structure of the ELMC on Google Drive

The structure of ELMC on Google Drive is determined by the need of saving the documentation and materials for all kinds of activities, which are envisaged in the curriculum of the discipline (lectures, laboratory, individual works, workshops) (Fig. 3). We recommended placing tasks for every laboratory work or workshop in a separate folder - in this case, it is possible to supplement, modify and delete resources with constant URL to the tasks in the Moodle course.

\subsection{Overview of the Structure of the Standard Moodle Course University}

The General section contains:

- teacher information (surname, first name and contact information);

- links to the curriculum or syllabus;

- links to excerpts from curriculum (syllabus) - tables with lectures' topics, laboratory and/or practical classes;

- links to the theoretical content folder (lecture materials, etc.);

- links to the electronic journal of the academic group (Moodle journal backup).

Three thematic sections were added to the course, which in this case contain only assignments. Students respond to the assignments by sharing links to the folder with the results of their work placed in the students' educational environments (student's Google Drive).

Also there are additional sections - giving extra points and final control (for example, the lecturer gives extra points if the student was present and showed activity; teacher gives the grade which the student received while answering the exam questions).

Standard Moodle course can be described by these criteria:

- structured teaching materials: availability of general and thematic sections, sections for additional and final assessment with clearly defined mandatory elements in them;

- the logic of the training course studying (the materials related to the course as a whole are placed at the beginning, after them - materials according to the curriculum and at the end - courses for the final assessment);

- a clear timetable for the completion of the curriculum (every assignment closes after deadline);

- the system of interactive interaction between the teacher and the students during in the course studying (there are a forum in the General section and communication facilities for consultations);

- quality of education materials (all course materials are published in ELMC on Google Drive);

- system of evaluation and control for all types of students' learning activities (all types of tasks are automatically displayed in the gradebook; every student has an opportunity to see only his own grades, 
the system records the date of the task submission and its' grade).

\section{Discussion}

\subsection{Restoring into an Existing Course. Editing the Structure and Content of Standard Moodle Course for the Requirements of the Teacher/Discipline}

\section{Restore Course from a Backup}

To develop a new Moodle course, it is enough to restore it from a backup of the standard Moodle course [6]. There are such ways of restoring course from a backup: restore as a new course (this option is available only for course managers), restore into this course or restore into an existing course. In our case, it is necessary to restore into this course, with the option "delete the content of this course and then restore".

\section{Editing Course Structure and Content}

We have to consider these questions of editing the structure and content:

- section editing (for example, the General section): fast (changes only the title) using the tool "Edit title"; summary, etc. - on the section editing page;

- editing links to files (curriculum or syllabus; tables with lectures topics, laboratory works and/or workshops; electronic gradebook, etc.) [6]. It is also worth to mention here that you can share the ELMC files hosted on Google Drive. If you work with the standard Moodle course university, we recommend sharing links to the ELMC folder and then copying the links to items;

- adding sections (for example, thematic or additional) and their moving;

- editing elements (for example, lab assignments - title, links to the task folder, gradebook, deadlines, etc.): fast - change only headings - tool "Edit title"; links to task folders, gradebook, etc. - on the page of editing the parameters of the task [6];

- adding new elements by duplicating existing ones (for example, assignments to sections or tests) and their moving;

- work with a questions bank (adding categories, import questions from file, and preparation of questions in different formats);

- editing tests: settings (quiz opening and closing time, time limit, allowed attempts, grading method, questions shuffle, adaptive or interactive mode, immediate or deferred feedback, etc.) and quiz (grades, shuffle, adding questions (a new question, from question bank, a random question) [8].

\section{Course Settings}

By default, the course page contains the Actions menu and the course content. You can add other blocks to make course navigation easier. For example:

- Activities (in a standard course they are forum, assignments and tests);

- Calendar with the specified events and deadlines.

By default, all the added blocks are located to the left under the Actions menu. We recommend placing the Calendar block to the right for better course navigation.

\section{Participants}

At this point, it is advisable to give students access to the course. It can be done in such ways: guest access (with or without password), self-registration (with or without password), manual enrollment (enrollment of students one at a time) and group synchronization. For group courses, it is advisable to use group synchronizing.

\section{Gradebook Setup}

After adding all the activities, you should review the Gradebook and make sure that the course total is 100 points.

If several groups are learning on the same course, the gradebook provides an over-view of the separate group, user or activity.

\section{Evaluation of Works}

To evaluate the assignment, you have to visit its' page where, by default, all students data is shown. At this stage, you can sort the data by one of such parameters: first/last name, e-mail, status (submitted for evaluation/not submitted; rated/not rated; submitted on time/delayed), rate, date of submission/last changes/rate change.

We recommend hiding some fields (such as e-mail, etc.).

On this page in the Options section you can filter the data: without submissions, submitted, evaluation required.

Thus, at the first evaluation, it is enough to set the filter to display the submitted works, at every next evaluation only "evaluation required", after the deadline - "without submissions".

\section{Course Backup}

Teachers should also pay attention to backing up their courses [6]. In this process such questions have to be considered:

- selection of course elements to back up;

- uploading the backup to the user's local disk. 


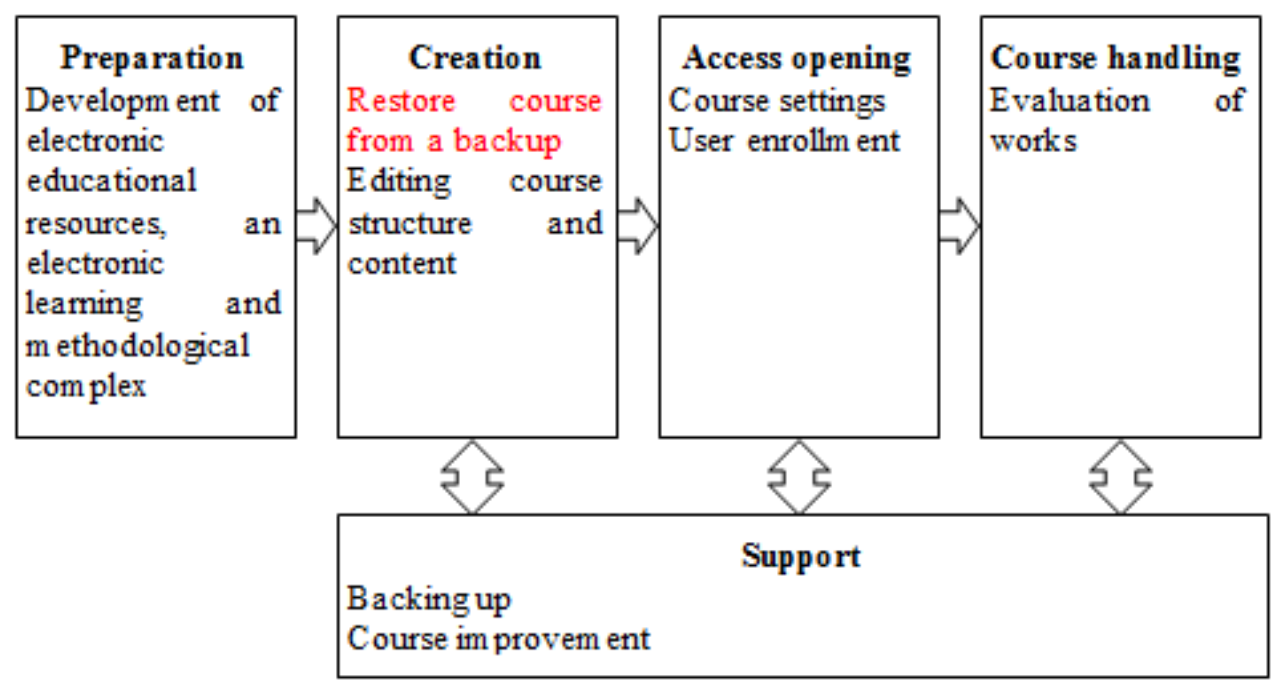

Figure 4. Scheme for designing a new course based on the standard Moodle course university

\section{Conclusions}

The Moodle course designing based on the standard Moodle course university does not overload the server.

All ELMC components are placed on the corporate Google Drive. The course author has the first backup of his course, since the original training content has been hosted on the local teacher's media. Designing your course basing on the standard Moodle course university takes less of time and reduces the minimal level of teachers' information and communication technologies competencies.

The survey "Designing of Moodle Courses Based on the standard Moodle course university" found that:

- $82 \%$ of respondents consider the idea of designing a standard Moodle course and designing new Moodle courses based on it;

- $34 \%$ of respondents consider the necessity of supplement the standard Moodle course university the with elements that reflect the features of the specialties.

Therefore, the prospect of further research is to take into account the features of different specialties, as well as the development of standard Moodle courses for other universities.

\section{REFERENCES}

[1] 2016 eLearning predictions hype curve. Adapted from Web Courseworks (2015). https://www.researchgate.net/figure/2 016-eLearning-predictions-hype-curve-Adapted-from-WebCourseworks-2015 fig1 322068935. Accessed 15 Apr 2020

[2] Bykov, V.Yu., Kukharenko, V.M.: Dystantsiinyi navchalnyi protses : navch. Posibnyk (Distance learning process: tutorial). Milenium, Kyiv (2005)
[3] Gaebel, M., Kupriyanova, V., Morais, R., Colucci, E.: E-Learning in European Higher Education Institutions: results of a mapping survey conducted in October-December 2013. EUA Publications, Brussels (2014)

[4] Havrushko, D.V., Romaniuk, V.M.: Instruktsiia po stvorenniu typovoho navchalno-metodychnoho kursu zasobamy MOODLE (Instruction for creating a standard training and methodological course using MOODLE tools). K-PNU im. IvanaOhiienka, Kamianets-Podilskyi, (2018)

[5] Isaienko, V.M., Kashyn, H.S., Nikolaiev, K.D., Pavliuchenko, L.S.: Navchalno-metodychnyi posibnyk dlia vykladachiv shchodo orhanizatsii dystantsiinoi formy navchannia $\mathrm{z}$ perepidhotovky ta pidvyshchennia kvalifikatsii (Educational and methodological manual for teachers on the organization of distance learning for retraining and professional development). Vydavnytstvo NPU im. M.P. Drahomanova, Kyiv (2014)

[6] Kryvyi Rih State Pedagogical University typical Moodle course.https://www.youtube.com/playlist?list=PLGLVt6cfu E67PzxHcXrE6xeTyfb5pA1J0 (2020). Accessed 15 Apr 2020

[7] Kukharenko, V.M., Berezenska, S.M., Buhaichuk, K.L., Oliinyk, N.Yu.,Oliinyk, T.O., Rybalko, O.V., Syrotenko, N.H., Stoliarevska, A.L.: Teoriia ta praktyka zmishanoho navchannia : monohrafiia (Blended learning theory and practice: a monograph) / In: Kukharenko, V.M. (ed.). Miskdruk, Kharkiv (2016)

[8] Mintii, I.S., Shokaliuk, S.V., Vakaliuk, T.A., Mintii, M.M., Soloviev, V. N.: Import test questions into Moodle LMS. In: Kiv, A.E., Soloviev, V.N. (eds.) Proceedings of the 6th Workshop on Cloud Technologies in Education (CTE 2018), KryvyiRih, Ukraine, December 21, 2018. CEUR Workshop Proceedings 2433, 529-540. http://ceur-ws.org/Vol-2433/p aper36.pdf (2019). Accessed 15 Apr 2020

[9] Mintiy, I.S., Kharadzjan, N.A., Shokaliuk, S.V.: IC competencies development of pedagogical higher educational institutions lecturers by certification training program "Information and communication technologies in the regular-distant (combined) learning". New computer technology 15, 240-244 (2017) 
[10] National Technical University "Kharkiv Polytechnic Institute" distance learning system. http://dl.khpi.edu.ua/. Accessed 15 Apr 2020

[11] Osvitnia platforma "Diia. Tsyfrova osvita" (Educational platform "Action. Digital Education"). https://osvita.diia.gov.ua/ (2020). Accessed 15 Apr 2020

[12] Osvitnii proiekt "Na Urok" (Education project "For lesson"). https://naurok.com.ua/webinar (2020). Accessed 15 Apr 2020

[13] Prokopenko, A.I., Pidchasov, Ye.V., Moskalenko, V.V., Dotsenko, S.O., Lebedieva, V.V. Tekhnolohii dystantsiinoho navchannia: metodolohiia stvorennia ta suprovodu navchalnykh kursiv. Navchalnyi posibnyk (Distance learning technologies: methodology for the creation and maintenance of training courses. Tutorial). Mitra, Kharkiv(2019)

[14] Rashevska, N.V., Semerikov, S.O., Slovak, K.I, Striuk, A.M.: Model kombinovanoho navchannia u vyshchii shkoli Ukrainy (The model of blended learning in the high school ofUkraine). In: Sbornik nauchnykh trudov (Collection of scientific papers), 54-59.Miskdruk, Kharkiv (2011)

[15] Semerikov, S.O., Striuk, A.M.: Kombinovane navchannia: problemy i perspektyvy zastosuvannia $\mathrm{v}$ udoskonalenni navchalno-vykhovnoho protsesu y samostiinii roboti studentiv (Blended learning: problems and prospects of improvement in the educational process and students' independent work). In: Konoval, O.A. (ed.) Teoriia i praktyka orhanizatsii samostiinoi roboty studentiv vyshchykh navchalnykh zakladiv (Theory and practice of organization of independent work of students of higher educational institutions), 135-163. Knyzhkovevydavnytstv oKyrieievskoho, KryvyiRih (2012)

[16] Smyrnova-Trybulska, Ye.M.: Teoretyko-metodychni osnovy formuvannia informatychnykh kompetentnostei vchyteliv pryrodnychykh dystsyplin u haluzi dystantsiinoho navchannia : dysertatsiia na zdobuttia naukovoho stupenia doktora pedahohichnykh nauk (Theoretical and methodological bases of formation of informative competences of teachers of natural disciplines in the field of distance learning : the dissertation for the degree of Doctor of Pedagogical Sciences). NPU im. M.P. Drahomanova, Kyiv (2008)

[17] Spirin, O.M., Vakaliuk, T.A.: Formation of information and communication competence of bachelors of informatics on the use of cloud-oriented learning environment. In-formation Technologies and Learning Tools. 4 (72), 226245 (2019). doi: https://doi.org/10.33407/itlt.v72i4.3262

[18] Striuk, A.M.: Teoretyko-metodychni zasady kombinovanoho navchannia systemnoho prohramuvannia maibutnikh fakhivtsiv z prohramnoi inzhenerii (Theoretical and methodological foundations of blended learning of system programming of future specialists in software engineering). Kryvyi Rih National University, Kryvyi Rih (2015).

[19] Teplytskyi, I.O., Semerikov, S.O., Polishchuk, O.P.: Model mobilnoho navchannia $\mathrm{v}$ serednii ta vyshchii shkoli (The model of mobile learning in middle and high school). In: Proceedings of the 3rd Ukrainian scientific and methodical workshop on Computer Simulation in Education, Kryvyi Rih, 24 Apr 2008, 45-46. KDPU, Kryvyi Rih (2008)
[20] Tryus, Yu.V., Herasymenko, I.V., Franchuk, V.M.: Systema elektronnoho navchannia VNZ na bazi MOODLE: metodychnyi posibnyk (MOODLE-based e-learning system : a toolkit). / In: Tryus, Yu.V. (ed.). Moodle.org, Cherkasy (2012)

[21] Tryus, Yu.V., Herasymenko, I.V.: The combined study as innovative educational technology in higher education. Theory and methods of e-learning 3, 299-308 (2012). Mode of access:https://ccjournals.eu/ojs/index.php/e-learn/article/ view $/ 353$

[22] Ustinova, V.O., Shokaliuk, S.V., Mintii, I.S., Pikilnyak, A.V.: Modern techniques of organizing computer support for future teachers' independent work in German language. In: Kiv, A.E., Soloviev, V.N. (eds.) Proceedings of the 6th Workshop on Cloud Technologies in Education (CTE 2018), KryvyiRih, Ukraine, December 21, 2018. CEUR Workshop Proceedings 2433, 308-321. http://ceur-ws.org/Vol-2433/p aper20.pdf (2019). Accessed 15 Apr 2020

[23] Zhytomyr Polytechnic State University. http://ztu.edu.ua. Accessed 15 Apr 2020

[24] Berdyansk State Pedagogical University. http://elearn.bdpu.org/. Accessed 15 Apr 2020

[25] Bogdan Khmelnytsky Cherkasy National University. https://dl.cdu.edu.ua/. Accessed 15 Apr 2020

[26] Borys Grinchenko Kyiv University. http://e-learning.kubg.e du.ua/. Accessed 15 Apr 2020

[27] Donbass State Pedagogical University. http://ddpu.edu.ua:9 090/moodle/login/index.php. Accessed 15 Apr 2020

[28] H.S. Skovoroda Kharkiv National Pedagogical University. http://lms.hnpu.edu.ua/moodle/. Accessed 15 Apr 2020

[29] Ivan FrankoLviv National University.http://e-learning.lnu.e du.ua/. Accessed 15 Apr 2020

[30] Kamianets-Podilskyi National Ivan Ohiienko University. https://itcentre.kpnu.edu.ua/moodle/. Accessed 15 Apr 2020

[31] Khmelnytskyi National University. https://msn.khnu.km.ua/. Accessed 15 Apr 2020

[32] KryvyiRih State Pedagogical University. https://moodle.kd pu.edu.ua/. Accessed 15 Apr 2020

[33] KSU Online Kherson State University. http://ksuonline.ksp u.edu/. Accessed 15 Apr 2020

[34] LesyaUkrainka Eastern European National University. http://cit.eenu.edu.ua/. Accessed 15 Apr 2020

[35] LuhanskTaras Shevchenko National University. http://do.lu guniv.edu.ua/. Accessed 15 Apr 2020

[36] Makarenko Sumy State Pedagogical University. https://dl.sspu.edu.ua/. Accessed 15 Apr 2020

[37] Mykolaiv V.O. Sukhomlynskyi National University. http://moodle.mdu.edu.ua/. Accessed 15 Apr 2020

[38] National Pedagogical Dragomanov University. https://moodle.npu.edu.ua/. Accessed 15 Apr 2020

[39] Pavlo Tychyna Uman State Pedagogical University. https://moodle.dls.udpu.edu.ua/. Accessed 15 Apr 2020

[40] Rivne State University of Humanities.http://do.iktmvi.rv.ua 
/. Accessed 15 Apr 2020

[41] Taras Shevchenko National University "Chernihiv College". https://moodle.chnpu.edu.ua/. Accessed 15 Apr 2020

[42] Ternopil Volodymyr Hnatiuk National Pedagogical University. http://elr.tnpu.edu.ua/. Accessed 15 Apr 2020

[43] Uzhhorod National University. https://e-learn.uzhnu.edu.ua/. Accessed 15 Apr 2020

[44] Vinnytsia Mykhailo Kotsiubynskyi State Pedagogical
University. http://distance.vspu.edu.ua/. Accessed 15 Apr 2020

[45] Volodymyr Vynnychenko Central Ukrainian State Pedagogical University. http://moodle.kspu.kr.ua/. Accessed 15 Apr 2020

[46] Yuriy Fedkovych Chernivtsi National University. https://moodle.chnu.edu.ua/. Accessed 15 Apr 2020

[47] Zhytomyr Ivan Franko State University. http://moodle.zu.edu.ua/. Accessed 15 Apr 2020 